\title{
Mechanical aortic valve thrombosis with severe valvular dysfunction treated with multiple rounds of thrombolysis
}

\author{
Muhammad Asim Shabbir (D) , 1,2 Muhammad Hamza Saad Shaukat, ${ }^{1}$ Evan Joye, ${ }^{3}$ \\ Scott Purga ${ }^{4}$
}

\begin{abstract}
'Department of Internal Medicine, Albany Medical Center Hospital, Albany, New York, USA

${ }^{2}$ King Edward Medical University, Lahore, Pakistan ${ }^{3}$ Department of Cardiology, Albany Medical Center Hospital, Albany, New York, USA ${ }^{4}$ Department of Cardiology, Capital Care Cardiology, Albany, New York, USA
\end{abstract}

Correspondence to Dr Muhammad Asim Shabbir; asimshabbir202@gmail.com

Accepted 15 February 2020

\section{DESCRIPTION}

A 27-year-old man with history of mechanical aortic valve due to isolated congenital aortic valve stenosis presented with dyspnoea, orthopnea and fatigue for 2 weeks. On arrival, he was in atrial fibrillation with rapid ventricular response in the range of $150 \mathrm{bpm}$. Other vital signs were normal. His examination revealed diffuse rales but was otherwise unremarkable. His complete blood count (CBC), electrolytes, erythrocyte sedimentation rate (ESR), $C$ reactive protein (CRP) and troponin-I were all normal. Brain natriuretic peptide (BNP) was 7580. International Normalized Ratio (INR) was subtherapeutic at 1.4; he was non-compliant with warfarin for 3 months due to insurance lapse. Chest X-ray revealed pulmonary vascular congestion, and he was treated using intravenous diuretics with good effect. Echo showed worsening cardiomyopathy with left ventricular ejection fraction (LVEF) 30\%-35\% (55\% a year ago) and suspicion for a mass on his mechanical aortic valve suggestive of thrombus versus vegetation. Transesophageal echocardiogram (TEE) revealed $5 \mathrm{~mm}$ thrombus on mechanical aortic valve prosthesis with severely reduced anterior leaflet excursion (video 1). Cardiothoracic surgery was consulted and favoured medical

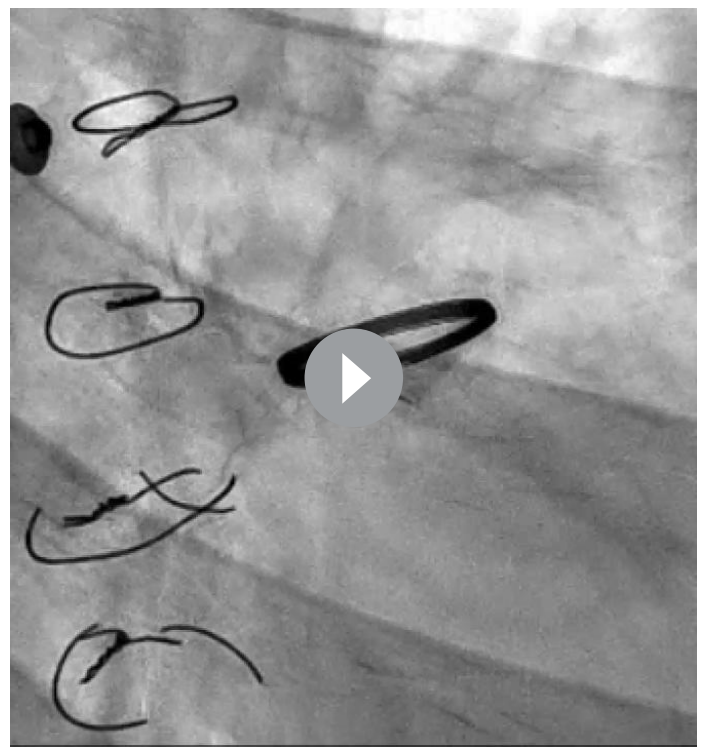

Video 1 Fluoroscopy showing severely reduced anterior aortic leaflet excursion.

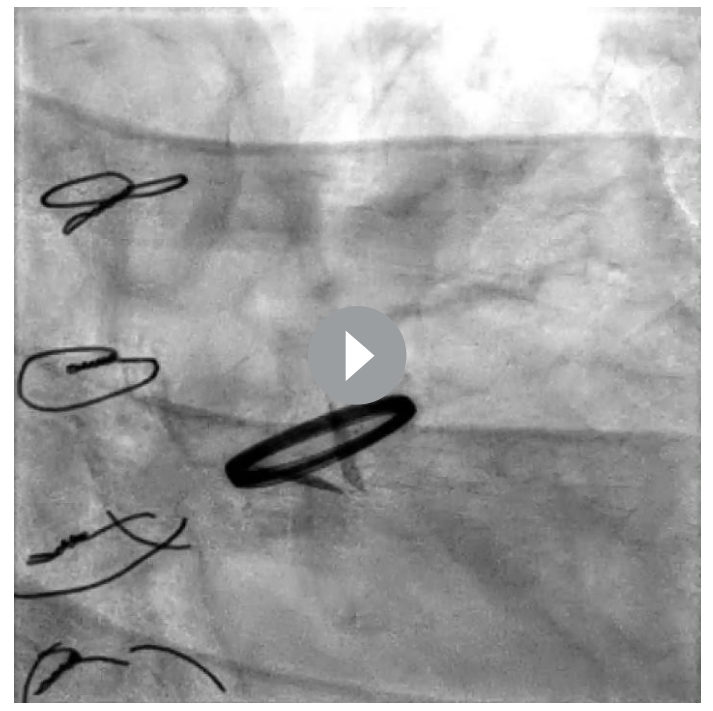

Video 2 Fluoroscopy showing improved anterior aortic leaflet motion after three rounds of alteplase infusion.

management due to small size of thrombus. Fluoroscopy was performed in cardiac catheterisation laboratory, which showed immobile anterior aortic leaflet. Alteplase (tPA) was given, $1 \mathrm{mg}$ per hour for 25 hours thorough peripheral intravenous line. This was followed by a 6-hour infusion of weight-based therapeutic unfractionated heparin (UFH). Re-fluoroscopy did not show any improvement in leaflet motion. Second dose of tPA ( $25 \mathrm{mg}$ over 25 hours) followed by 6-hour UFH infusion was administered with no good results on fluoroscopy. Patient finally received third infusion of tPA which led to left arm bruising as well as swelling. Auscultation now revealed sharper sounding mechanical valve clicks. Repeat fluoroscopy confirmed much better valve movement with improved leaflet excursion (video 2). UFH was overlapped with warfarin until the goal INR (2.53.5) was achieved. Upper extremity bruising and swelling resolved spontaneously. He was fitted for a life vest given his depressed ejection fraction and risk of sudden cardiac death, medically optimised for his left ventricular (LV) dysfunction and discharged on warfarin with very close outpatient follow-up. Detailed discussion was undertaken regarding importance of medication adherence.

Mechanical aortic valve thrombosis is a rare but serious prosthesis complication. The annual rate of prosthetic mechanical valves ranges from 


\section{Learning points}

- Treatment of mechanical valve thrombosis is either surgery or thrombolysis based on thrombus size and presence of obstruction.

- Repeated attempts of thrombolysis are sometimes required to recover valvular function. Risk of bleeding and other complications needs to be weighed while making decision.

$0.1 \%$ to $5.7 \%$ with even higher rate in patient not adherent to anticoagulation therapy. ${ }^{1}$ Diagnosis can be made by examination, TEE and fluoroscopy; we used the latter modality to assess tPA treatment effect. ${ }^{2}$ Treatment is either surgery or thrombolysis based on thrombus size and presence of obstruction. ${ }^{3}$ The major risk of fibrinolytic treatment is bleeding and systemic emboli, including stroke. Our case is unique in that we demonstrate safe use of three rounds of tPA. Fortunately, our patient did not have any immediate complications perhaps because of small thrombus size. We performed extensive education about compliance and planned for close follow-up to avoid future catastrophic events in this young patient.

Contributors MAS wrote the main manuscript. MHSS designed and drafted the manuscript with main author. EJ edited the script. SP supervised and gave medical insights.

Funding The authors have not declared a specific grant for this research from any funding agency in the public, commercial or not-for-profit sectors.

Competing interests None declared.

Patient consent for publication Obtained.

Provenance and peer review Not commissioned; externally peer reviewed.

\section{ORCID iD}

Muhammad Asim Shabbir http://orcid.org/0000-0001-8275-3847

\section{REFERENCES}

1 Dangas GD, Weitz Jl, Giustino G, et al. Prosthetic heart valve thrombosis. J Am Coll Cardiol 2016:68:2670-89.

2 Montorsi P, De Bernardi F, Muratori M, et al. Role of cine-fluoroscopy, transthoracic, and transesophageal echocardiography in patients with suspected prosthetic heart valve thrombosis. Am J Cardiol 2000;85:58-64.

3 Roudaut R, Serri K, Lafitte S. Thrombosis of prosthetic heart valves: diagnosis and therapeutic considerations. Heart 2007;93:137-42.

Copyright 2020 BMJ Publishing Group. All rights reserved. For permission to reuse any of this content visit

https://www.bmj.com/company/products-services/rights-and-licensing/permissions/

BMJ Case Report Fellows may re-use this article for personal use and teaching without any further permission.

Become a Fellow of BMJ Case Reports today and you can:

- Submit as many cases as you like

- Enjoy fast sympathetic peer review and rapid publication of accepted articles

- Access all the published articles

- Re-use any of the published material for personal use and teaching without further permission

\section{Customer Service}

If you have any further queries about your subscription, please contact our customer services team on +44 (0) 2071111105 or via email at support@bmj.com.

Visit casereports.bmj.com for more articles like this and to become a Fellow 